Лілія КАЧУРИНЕЦЬ,

orcid.org/0000-0002-7800-789X

викладач кафедри вокалу та диригентсько-хорових дисциплін Хмельницької гуманітарно-педагогічної академії

(Хмельницький, Україна) Kachurinec@mail.ru

\title{
ВІРТУАЛЬНИЙ ХОР ЯК НЕОБХІДНИЙ ПЕДАГОГІЧНИЙ ДОСВІД В УМОВАХ ДИСТАНЦЙНОГО НАВЧАННЯ
}

\begin{abstract}
Стаття присвячена дослідженню актуальних проблем організації дистаниійної хорової практики як необхідного забезпечення навчальної дисципліни «Хоровий клас та практика роботи з хором». Розглянуто причини, які зумовили потребу трансформаиї хорового мистеитва засобами комп 'ютерних технологій? та їхні можливості використання у створенні віртуального хору. Проаналізовано досвід твория нової форми хорового мистеитва, американського диригента - Еріка Вайтекера. Запропоновано власну експериментальну практичну роботу та деталізовано поетапні кроки створення віртуального хору. Зокрема, навесні 2020 року на базі Хмельницькоі гуманітарно-педагогічної академії автор статті здійснила експериментальну роботу зі створення віртуального хору, репетииї хору частково здійснювалися на ичирровій платформі Zоот. Початковим етапом роботи слугувало повідомлення про ідею створення віртуального хору та вибір музичного твору, вибір концепції реалізації задуманого й усвідомлення дій колективу на відстані. Наступним кроком був відеозапис диригування схеми хормейстером зі всіма вступами та проведеннями тем хорових партій, аудіозапис гри хорової партитури кониертмейстером для дотримання одночасного темпо-метро-ритмічного ансамблю учасниками колективу. Черговим і об'смним етапом у створенні віртуального хору постав аудіозапис окремо кожної хорової партії. Наступний етап у створенні віртуального хору - збір, синхронізація, перенесення аудіофайлу на комп'ютер, обробка та зведення аудіофайлів виконання кожної партії в хоровий ансамбль. Наостанок-запис відеофайлів та представлення їх в «екранному світі».

Потреба здійснювати хорову практику в умовах дистанційного навчання змусила диригентів та керівників хорів шукати альтернативних способів реалізації хорового мистецтва, у результаті з 'явився новий мистецький продукт - віртуальний хор. Поглиблення інтеграції мистеццтва й освіти засобами віртуальних комп 'ютерних технологій можна вважати перспективним напрямом подальших досліджень.
\end{abstract}

Ключові слова: віртуальний хор, комп'ютерні технології, педагогічний досвід, дистанційне навчання.

Liliia KACHURYNETS, orcid.org/0000-0002-7800-789X Lecturer at the Department of Vocal and Conducting-Choral Disciplines Khmelnytskyi Humanitarian-Pedagogical Academy (Khmelnytskyi,Ukraine) Kachurinec@mail.ru

\section{VIRTUAL CHOIR AS A NECESSARY PEDAGOGICAL EXPERIENCE UNDER THE CONDITIONS OF DISTANCE LEARNING}

The article deals with the research of actual problems of organization of distance choral practice as a necessary provision of the discipline "Choral Class and Practice of Work with Choir". The reasons for the need to transform choral art by means of computer technology and their possibilities of use in creating a virtual choir have been considered. The experience of the creator of the new form of choral art, the American conductor-Eric Whitaker has been analyzed. Our own experimental practical work has been offered and the phased steps of creating a virtual choir have been detailed. In particular, in the spring of 2020, on the basis of the Khmelnytskyi of Humanitarian-Pedagogical Academy, the author of the article carried out experimental work to create a virtual choir, the rehearsals of the choir were partially carried out on the digital platform Zoom. The initial stage of the work was a message about the idea of creating a virtual choir and the choice of a musical work, the choice of the concept of realization of the plan and awareness of the actions of the team at distance. The next step was a video of the conducting of the scheme with all the introductions and themes of the choral parts and audio recording of the choral score by the concertmaster to observe the simultaneous tempo-metro-rhythmic ensemble by the members of the collective body. The next and voluminous stage in the creation of the virtual choir was the audio recording of each choir part separately. The next step in creating a virtual choir was to collect, synchronize, transfer the audio file to the computer, process and compile the audio files of each part into the choir ensemble. Finally, we recorded video files and presented them in the "screen world".

The need for choral practice under the conditions of distance learning has forced conductors and choir directors to look for alternative ways to implement choral art, and as a result, the new art product has emerged-the virtual choir. Deepening the integration of art and education through virtual computer technology can be considered a promising area for further researches.

Key words: virtual choir, computer technologies, pedagogical experience, distance learning. 
Постановка проблеми. Сучасні події, зумовлені розповсюдженням у світі вірусу Covid-19 навесні 2020 р., спричинили в закладів мистецької освіти України різного рівня акредитації гостру потребу в організації дистанційного навчання в умовах карантину, базових змін у традиційних іiі формах. У педагогічній спільноті постала нагальна потреба в набутті й апробації досвіду організації викладацької діяльності за допомогою цифрових засобів та комп'ютерних технологій. Безпосередньо викладач диригентсько-хорових дисциплін опинився перед потребою подолання проблеми проведення практичних групових занять в умовах дистанційного навчання, що зумовило виявлення цікавих педагогічних знахідок, зокрема створення віртуального хору.

Причинами «розквіту» останнього слугувала потреба у зміні способу мислення, зумовлена умовами карантину, та гостра необхідність збереження хорового мистецтва, що спонукало керівників навчальних хорових колективів до вивчення проблем організації дистанційного хорової практики та швидкого опанування різних сучасних комп'ютерно-дистанційних можливостей як належного забезпечення навчальної дисципліни «Хоровий клас та практика роботи з хором» в умовах дистанційного навчання.

Аналіз досліджень. Феномен сучасного віртуального мистецтва $є$ продовженням технологічного мистецтва кінця XX ст., а також відгалуженням від нього, створеним людською діяльністю зі специфічними властивостями. Ця схильність до відкритості у віртуальному мистецтві простежується в теоріях Мануеля Кастельса, Умберто Еко й Елвіна Тоффлера (Schroeder, 1996).

Американський мистецтвознавець та скульптор Джек Бернем (Beyond Modern Sculpture, 1968) у процесі дослідження віртуального мистецтва, яке може охоплювати віртуальну реальність, убачав його в таких творах, як відеоігри та фільми.

Американський теоретик медіамистецтва Джин Янгблуд (Expanded Cinema, 1970) уважав, що віртуальне мистецтво особливо ефективно буде виникати в абсолютно новому медіа, оскільки «технічна машина не $є$ виразним засобом» (Hegarty, 2015: 19).

У науковій праці «Від технологічного до віртуального мистецтва» американський кінорежисер Френк Поппер простежує віртуальне мистецтво в гуманізації технологій, акценті на його інтерактивності, понятті мультисенсорного характеру (Popper, 2007).

Сучасні українські науковці А. Заболоцький (Заболоцький, 2016: 19-23), Ю. Іванов, О. Ольхов- ська, Д. Ольховський (Іванов та ін., 2017: 58-62) у дослідженням розглядали питання застосування комп'ютерних технологій дистанційного навчання у вищій освіті.

Захар Дубовий у дисертаційній роботі досліджував дистанційне навчання як сукупність сучасних інноваційних педагогічних та інформаційних технологій, зокрема мультимедійних, мережевих, музично-комп'ютерних, технологій електронного, комбінованого й змішаного навчання, що забезпечують доставку інформації в інтерактивному режимі від тих, хто навчає, до тих, хто навчається (Дубовий, 2019: 200).

Мета статті. Незважаючи на деякі здобутки у вивченні питання дистанційної освіти, у мистецькій педагогіці донині бракує цілісного дослідження віртуальної хорової практики, ії виявів у сучасному інформативному просторі, трансформації вокально-хорового мистецтва, застосування комп'ютерних технологій i, урешті-решт, появи віртуального хору. Мета статті полягає в окресленні практичних аспектів роботи з віртуальним хором в умовах дистанційного навчання.

Виклад основного матеріалу. Генеза української музичної культури тісно пов'язана з хоровим мистецтвом, бо хоровий спів - вагоме надбання в царині духовності народу. «Хор - це колектив співаків, у звучності якого є строго витриманий ансамбль, абсолютно вивірений лад і художні, чітко вироблені нюанси» (Чесноков, 1961: 21).

Хор як колектив співаків, хоровий спів як вид колективної виконавської діяльності, хорова музика як наймасовіший вид музичного мистецтва, хорова практика як мотивація до здійснення професійної діяльності, хорознавство як наука про хорове мистецтво - ці об'єкти наукових розвідок давно досліджені в колі науковців, серед яких П. Чесноков, К. Пігров, Г. Дмитревський, О. Єгоров, В. Соколов, В. Живов, П. Левандо, Ю. Кузнєцов, О. Коломоєць, Т. Смирнова, Н. Бєлік-Золотарьова, Ю. Іванова й інші.

Технічна комп'ютеризація XXI ст. принесла оновлення для світу хорової музики. Віртуальний хор - поняття нове та маловивчене. Щоб пояснити появу віртуального хору, ми звернемося до багатої спадковості віртуального мистецтва.

Дмитро Іванов зазначав: «Віртуалізація - це будь-яке заміщення реальності іiі симуляцією, образом» (Шадських, 2012: 73-78). Найчастіше об'єкти віртуальності (віртуального світу) мають властивості, відповідні об'єктам реального світу, але можуть мати властивості, що відрізняються від них (аж до протилежних). Наприклад, у віртуальності досить легко уявляти (сфантазувати) «анти- 
гравітацію» або «вічне життя», а також предмети 3 будь-якими властивостями і можливостями. Також у віртуальності можна порушувати причинно-наслідкові зв'язки (Волинець, 2014: 36).

Джек Бернем під час дослідження віртуального мистецтва підкреслював його відкритість і з погляду митців і їхньої творчості, і $з$ погляду глядачів, які продовжують дотворення у своєму мисленні та діях. 3 розвитком технологій віртуальне мистецтво швидко трансформується, стає більш значним i популярним, охоплює безліч комп'ютерних програм, проявляється в анімації, фільмах, відеоіграх, відеокліпах тощо.

Нині термін «віртуальне мистецтво» тлумачиться багатозначними поясненнями 3 невиразними межами і відображає поняттєву, предметну й функціональну подібність явищ. Ми пов'язуємо віртуальне мистецтво з телебаченням, інтернетом, електронними засобами комунікацій, комп'ютерними програмами тощо.

Отже, віртуальність (від лат. virtus - «потенційний», «можливий») - вигаданий, уявний (можливо, для визначених цілей) об'єкт, суб'єкт, категорія, ставлення, дія тощо, не присутній у цей час у реальному світі, а створений лише грою уяви людської думки, або зімітований за допомогою інших об'єктів (Волинець, 2014: 36).

Віртуальний хор ми визначаємо як нову форму побутування уявного хорового колективу з необмеженою кількістю співаків, що імітує та створює за допомогою доступних мультимедійних ресурсів враження особистої присутності в режимі реального часу у стереоскопічно поданому екранному середовищі.

На думку Еріка Вайтекера, віртуальний хор це глобальне явище, яке формує створений користувачами соціальних мереж хор, що завдяки використанню технологій по-новому об'єднує співаків 3 усього світу та їхню любов до хорової музики. Співаки записують і завантажують відео із власного місця перебування по всьому світу. Потім кожне відео синхронізується й об'єднується в один спектакль для створення віртуального хору.

Уперше віртуальний хор з'явився на просторах інтернету у 2009 р. Творцем нової форми хорового мистецтва $\epsilon$ Ерік Вайтекер - володар головної музичної нагороди американської академії звукозапису Греммі, американський композитор, диригент, оратор, який уславився хоровою, оркестровою й ансамблевою музикою (Віртуальні хори, 2018). Його концертну музику виконували в усьому світі мільйони аматорських та професійних музикантів, водночас його новаторські віртуальні хори об'єднали співаків зі 145 різних країн. Ерік Вайтекер розробив докладні методичні рекомендації щодо виконання віртуальних творів, 3 якими можна ознайомитися на сайті композитора (https://ericwhitacre.com). Хормейстер наголошує на характерних особливостях нової хорової форми, як-от: споглядальний характер, помірний темп, акордовий склад із численними секундовими нашаруваннями, кластерами, розщепленням голосів на divisi (до 18 голосів). Наприклад, чотири віртуальні хори Е. Вайтекера: "Lux Aurumque" (2009 р.) - задіяно 185 хористів із 12 країн, "Sleep" (2011 р.) - 2052 хористи 358 країн, "Water Night" (2012 p.) - 4000 хористів із 73 країн, "Fly to Paradise" (2013р.) - 5905 хористів зі 101 країни.

Завдяки сорока мільйонам переглядів відеоролику віртуальний хор показали на телебаченні (АВС у США та ВВС у Великобританії) та як інсталяцію по всьому світу, зокрема й на заключному пленарному засіданні Всесвітнього економічного форуму в Давосі (2013 р.). Віртуальний хор презентували на головній сцені конференції TED ${ }^{1}$, Центрі Пейлі в Нью-Йорку, Центрі Кеннеді у Вашингтоні на заходах для Google, ЮНІCЕФ та ООН.

В Україні віртуальний хор з'явився як нагальна умова існування навчальної практики в умовах дистанційного навчання, як нова технологія безконтактної інформаційної взаємодії.

Відповідно до постанови Кабінету Міністрів України від 11 березня 2020 р. № 211, у навчальних закладах із 12 березня 2020 р. встановлено карантин, який передбачає заборону відвідування учасниками освітнього процесу закладів освіти всіх типів та форм навчання. Перед педагогами нагально постало питання організації дистанційного навчання, медіаграмотної ефективної взаємодії на відстані.

Дистанційна освіта - метод викладання, за яким учень та викладач фізично перебувають у різних місцях. Він передбачає поєднання різних інформаційних технологій: проведення аудіо- та відеоконференцій, обмін текстовими повідомленнями, демонстрацію електронних ресурсів різних форматів: презентацій, роликів, вебсторінок; обмін файлами, вебтури, опитування, тестування з миттєвою візуалізацією, можливостями збереження відеозапису для подальшого використання в навчанні.

\footnotetext{
TED - некомерційна організація у США, яка поширює ідеї, що повинні змінити світ. Конференція TED славиться лекціями (TED Talks), які спочатку були зосереджені на технологіях, розвагах та дизайні, але згодом охопили також природничі науки, мистецтво, освіту, культуру, бізнес, глобальні проблеми, сталий розвиток - широкі сфери тем, що разом формують наше майбутнє; зазвичай у формі коротких бесід (приблизно 18 хвилин, адже саме цей час аудиторія зберігає уваг без втрати інтересу до доповіді).
} 
Перелік освітніх платформ та інструментів для реалізації дистанційної освіти сьогодні досить різноманітний: від використання звичайного електронного листування до масових відеозаходів онлайн. Звичайно, це викликає певну розгубленість у викладача як користувача такими продуктами та потребує спеціального навчання.

Викладачів мистецької сфери освіти особливо цікавлять платформи, які б дозволяли бачити вихованців і те, що вони роблять. Засобами в реалізації завдань мистецької освіти стали ресурси, що насамперед забезпечують відеозв'язок та надають можливість викладачеві передавати інформацію (знання, уміння, завдання, досвід) учневі за допомогою можливості чути та бачити один одного, зокрема такі цифрові сервіси, як Zoom, Skype, Viber, Telegram тощо. Серед прийомів дистанційної мистецької освіти доцільно використовувати: авторський блог, створення коротких онлайнроликів на різні теми, підготовку та розсилку аудіоповідомлень із завданнями (аудіозавдання для слухового аналізу, відеорозспівки), аналіз відео-, аудіозаписів,ресурсів;участьвінтернет-конкурсах.

На нашу думку, основною складністю дистанційного мистецького навчання $\epsilon$ проведення групових занять для виконавських дисциплін, зокрема хорового класу. Обмеження практичного контролю керівника хору за виконанням вокально-технічних вправ хористом, спотворений звук у зв'язку з уповільненням його передачі через різні швидкості інтернету, скривлена постановка корпусу та голови під час застосування електронних пристроїв, відсутність єдиного способу співацького дихання і звукоутворення тощо - нові диригентські труднощі в розвитку вокально-хорових навичок із метою досягнення краси та виразності звучання співочих голосів у процесі виконання хорових творів.

Навесні 2020 р. на базі Хмельницької гуманітарно-педагогічної академії автор статті здійснила експериментальну роботу зі створення віртуального хору для виконання української народної пісні в обробці Ольги Токар «Солоха» a cappella. У цьому були задіяні 25 хористів, які перебували поза навчальним закладом та не контактували один 3 одним. Репетиції хору частково здійснювалися на цифровій платформі Zoom. Завдяки відеозв'язку було проведено заняття, що можна класифікувати як відеоурок, що складається зі вступу, змістовної частини, питань-відповідей, інструктажу до домашнього завдання та заключної частини.

Початковим етапом роботи є повідомлення про ідею створення віртуального хору та вибір музичного твору, вибір концепції реалізації задуманого й усвідомлення дій колективу на відстані, адже «ми свідомо в уяві створюємо ситуацію бажаної події, персонажів, які беруть участь у ній, вибудовуємо послідовність дій і ситуацій, тобто фактично виступаємо режисерами й акторами створюваного нами віртуального спектаклю. Невипадково естетика вже давно визнала в кожній людині (особливо в дитині) художника, але тільки деяким вдається довести свою творчість до вираження в чуттєво сприйманих матеріалізованих формах мистецтва, а в більшості їхня творчість залишається у свідомості на рівні уявних світів» (Бычков, 2006).

У зв'язку із цим доцільно звернутися до сучасного інструменту репетиційної підготовки соціальних мереж (вебсервіси), які дають можливість користувачам, студентам та викладачам, створювати публічний або частково публічний профіль у рамках системи; формувати список інших користувачів, з якими вони взаємопов'язані; переглядати список контактів та керувати ним, переглядати списки, створені іншими користувачами; оперативно ділитися зі студентами важливою інформацією тощо. У деяких соціальних мережах (facebook.com, twitter.com youtube.com та інші) $\epsilon$ великий вибір додатків, які можна застосувати 3 навчальною метою. Можливість постійної дистанційної взаємодії студентів і викладачів у мережі у зручний для них час забезпечує безперервність навчального процесу. Студенти самі створюють контент, використовують інтерактивне відео та посилання на цікаві вебресурси, поширюють його серед інших користувачів. У контенту є унікальна адреса (URL), яка дає можливість робити посилання із зовнішніх ресурсів. У всіх активних учасників мережі $є$ профіль на сайті, пов'язаний 3 іншими учасниками, з контентом і з іншими надбудовами та можливостями платформ. Віртуальна група (хор), створена в соціальній мережі, може бути доступна для суб'єктів навчального процесу в будь-якому місці й у будь-який час.

Наступним кроком у створенні віртуального хору $є$ відеозапис диригування схеми хормейстером зі всіма вступами та проведеннями тем хорових партій, аудіозапис гри хорової партитури концертмейстером для дотримання одночасного темпо-метро-ритмічного ансамблю учасниками колективу.

Особливою функцією хормейстера у відеозаписі диригування схеми $є$ не тільки організація спільних колективних дій, дотримання власного художнього бачення, формування єдиної виконавської стратегії й тактики втілення художнього задуму, а й віртуальне спілкування 3 колективом. Диригент, коли працює над відеозаписом схеми, 
не тільки звертає увагу на організацію темпу, ритму, метру, характеру звуковедення, динаміки, початку і закінчення звучання, проведення сольних партій або виділення головних тем, але й виявляє та передає заряд віртуально-почуттєвої енергії для виконання художнього задуму, активізації емоційної сфери кожного виконавця. Диригент, який керується в діях внутрішнім слуховим сприйняттям ідеального задуму, повинен відчувати кінцевий результат.

Вагомим помічником у цьому $\epsilon$ аудіозапис гри хорової партитури концертмейстером, що виступає як засіб імітації загального хорового ансамблю. Особливість вокально-хорової роботи під фортепіанний запис партитури в тому, що хорист як один учасник, орієнтується на уявлену ним звучність співу, чує реальне виконання хорової партитури концертмейстером на фортепіано, що забезпечує стабільне рівне темпо-метро-ритмічне ансамблеве виконання, полегшує конструювання чистої інтонації гармонічного та мелодичного строю, попереджає слухові рецептори щодо зміни динамічних нюансів.

Черговим та об'ємним етапом у створенні віртуального хору став аудіозапис окремо кожної хорової партії. Починаючи працювати сольфеджіо над мелодичною лінією, чистотою інтонування, будуванням музичних фраз, цезури, дихання, відтворення емоційного змісту літературної мови, кожний хорист записував декілька разів свій аудіофайл тр3-формату на диктофон мобільного телефону та надсилав хормейстеру через цифрову платформу Viber або Telegram для детального аналізу та подальшої корекції звучання. Під час роботи над віртуальним хором кожному хористу частково самостійно потрібно працювати над усіма вокально-хоровими завданнями водночас. Ускладнює процес такої аудіороботи і наявність якісного мобільного зв'язку, нових електронних пристроїв і у студентів, і в керівника.

Функції нових комп'ютерних технологій, різноманітних гаджетів (мобільні телефони) загалом надзвичайно широкі, але нас, зокрема, цікавить їхне використання з такими цілями:

a) вибір, накопичення та відтворення окремих музичних речень і сольфеджіо, і з літературним текстом;

б) наявність програм для редагування звукової інформації в цифровому звукозаписі, наприклад, програмиSoundForge,якадозволяєкорекціюзвукукопіювання, вирізання, вставку, видалення фрагмента, заглушення фрагмента, конвертацію тощо;

в) запис звукової доріжки MIDI й аудіо «живого» виконання співака або інструментального супро- воду до хорового твору в цифровому форматі, 3 подальшим їх зберіганням на комп'ютерних носіях і обробкою у програмах-редакторах звуку;

г) зведення голосів, аранжування й обробка записів;

г) відеозапис співу виконавця.

Щоб записати аудіофайл окремо кожної хорової партії на мобільний носій (телефон), потрібно вміти користуватися програмою звукового запису. Зазвичай виробники мобільних носіїв комплектують вироби набором різних програм, зокрема й програмою запису голосу. Іноді така програма не входить у комплект. Тому ми пропонуємо завантажити з Google Paly безкоштовну програму запису голосу, наприклад, популярний додаток Smart Voice Recorder. Після відкриття програми для старту запису потрібно натиснути кнопку Start Recording. Під час запису на великій червоній кнопці буде демонструватися відлік часу, що пройшов від початку, а над кнопкою буде видно роботу індикатора рівня запису. Під час запису треба співати в область мікрофону або тримати смартфон перед собою. Після завершення запису відкриється вікно збереження записаного голосу, що містить дату його створення, тривалість і обсяг аудіофайлу. Далі потрібно знайти елемент управління програванням, за допомогою якого можна прослухати записаний голос. Готовий записаний голос хорової партії можна надіслати за допомогою інтернету через цифрову платформу Viber або Telegram керівнику.

Як бачимо, загалом мобільно-технічні записи можуть використовуватись для створення, збереження інформації та як інструмент контролю i самоконтролю якості виконання.

Наступний етап у створенні віртуального хорузбір, синхронізація, перенесення аудіофайлу на комп'ютер, обробка та зведення аудіофайлів виконання кожної партії в хоровий ансамбль.

Прийняті записані аудіофайли потрібно перенести на комп'ютер. Розглянемо два варіанти перенесення аудіофайлу на комп'ютер: через хмарне сховище та у вигляді вкладення в електронний лист. Щоб вибрати варіант відправки файлу, потрібно виділити аудіо голосу і за допомогою переліку додаткових дій «відправити <...>» 3 можливими варіантами пересилання обраного файлу.

Передача 3 використанням будь-якого хмарного сховища однотипна. Усі сховища використовують загальну концепцію - синхронізацію даних на різних приладах користувача. Так, досить установити на кілька пристроїв програму, наприклад, Dropbox, та підтвердити в ній папку (контейнер для збереження інформаціі), яку треба синхроні- 
зувати. Далі досить помістити в таку папку будьякий аудіофайл, і він з'явиться на всіх пристроях, підключених до хмарного сервісу.

Щоб перенести аудіофайл на комп'ютеру вигляді електронного листа, потрібно вказати адресу електронної пошти одержувача і прикріпити аудіофайл повідомленням. Важливо, щоб лист можна було відкрити на комп'ютері та зберегти прикріплений до нього файл в підготовлену папку у файловій системі. Перенесені на комп'ютер аудіофайли потрібно перевірити i, у разі потреби, відредагувати.

Єднання аудіофайлів у монолітний віртуальний хор здійснюється за допомогою програм багатоканального зведення - програмного забезпечення, що дозволяє редагувати звук на кількох незалежних одна від одної звукових доріжках, а також зводити їх в одне звукове ціле (Вікіпедія).

Наведемо приклад використання програми, призначеної для професійної й аматорської обробки аудіофайлів, аудіомікшування, редагування, мультитрекового монтажу та мастерингу аудіозаписів, - Adobe Audition.

Інструментарійпрограминадаєтакіможливості:

1) редагування окремих аудіофайлів, створення циклів, імпорт вбудованих і зовнішніх аудіоефектів, мікшування до 128 звукових треків;

2) мультитрековий режим дозволяє змонтувати окремий твір;

3) у режимі Multitrack за допомогою вбудованої панелі Sequencer можна створювати власний музичний твір;

4) обробка аудіодоріжки відеофільмів формату AVI;

5) експорт та імпорт аудіотреків;

6) відновлення старих записів із вінілових платівок, аналогової плівки й інших носіїв;

7) набір інструментальних засобів роботи 3 інтерфейсом MIDI дозволяє створення музичних композицій у мультитрековому режимі;

8) підтримуються засоби інтеграції із програмами Adobe Premiere i After Effects (Степаненко, 2010: 97).

Програма Adobe Audition проста в організації ефективного виконання всіх операцій із групами аудіофайлів та зручна для роботи панелями інструментів, за допомогою звукової карти дозволяє зчитувати аудіофайли, зводити та записувати ïx у єдине ціле у форматі mp3. За допомогою мікшера та засобів автоматизації параметрів хормейстер значно розширює художнє бачення та творчі можливості. За допомогою програми керівник хору отримує суттєву можливість створити багатоголосний хоровий твір, монтувати WAV-файл та отримати кінцевий продукт.
Останній етап створення віртуального хору запис відеофайлів та представлення їх в «екранному світі».

Записувати відео в реальному часі можна 3 використанням телефонних носіїв за допомогою додатку Google-камери. Щоб оптимізувати якість відеозапису, потрібно не закривати його невеликі отвори мікрофонів та тримати телефон горизонтально за довгі краї.

Після отримання відеофайлів аналогічним способом, як i аудіо, починається робота над монтажем відеокліпа, наприклад, за допомогою безкоштовної програми VivaCut - професійного редактора для створення відеороликів. У цьому відеоредакторі можна монтувати цілі відеоісторії 3 використанням різних фільтрів і багатошарової тимчасової шкали. Інструментарій програми надає такі можливості:

а) професійне редагування відео;

б) великий вибір інструментів, фільтрів і стікерів;

в) можливість редагування 3 масштабуванням для максимальної покадрової точності; обрізка відеокліпів здійснюється з великою точністю;

г) можливість накласти музику на відео;

г) функція «картинка в картинці» - можливість об'єднувати кліпи для створення подвійного ефекту (VivaCut, 2020).

Потрібно констатувати, що VivaCut надає користувачам всі засоби, необхідні для ефективного редагування та створення відео «екранного світу». У програмі впроваджені найбільш передові технології перетворення відеоданих і їхнє редагування. Р. Петелін уважає, що для ефективного застосування програми бажано володіти знаннями в галузі акустики, математичних методів синтезу й обробки сигналів, програмування, спектрального аналізу, теорії фільтрації, теорії музики, навичками режисури (Петелин, 2010: 15).

Опанування комплексу знань, умінь та навичок роботи в аудіоредакторах та відеопрограмах дозволить керівнику хорового колективу записувати, редагувати, компонувати, обробляти цифровий звук, а також створювати цілі відеоспектаклі або відеокліпи, як-от віртуальний хор.

На наш погляд, запровадження таких кінцевих продуктів роботи хорового класу в умовах дистанційної мистецької освіти породжує новий вид віртуального мистецтва, побудований засобами комп'ютерних технологій, що стає необхідним способом буття вокально-хорової практики. Власне підгрунтям віртуалізації хорового колективу насамперед слугують комунікативні інновації, формуванню яких сприяють комп'ютерні 
й інтернет-технології. Безумовно, застосування такого досвіду дистанційного навчального курсу «Хоровий клас і практикум роботи 3 хором» в освітньому середовищі вітчизняних вищих педагогічних навчальних закладів та сучасних інформаційно-комунікаційних технологій ще незначне, його варто поширювати й використати як потребу збереження хорової культури.

Отже, можливості такого потрібного педагогічного досвіду можна використовувати для підготовки майбутніх хорових диригентів; керівників навчальних, аматорських та професійних хорових колективів; дистанційного мистецького навчання. Він потребує подальшого вивчення, осмислення, методично-технічного забезпечення та педагогічної підготовки.
Висновки. Підсумовуючи вищесказане, можемо констатувати, що швидкі зміни умов i «правил» життя в сучасному світі викликають зміщення акцентів у формі існування та розвитку мистецтва й освіти, що спричиняє все більше і ширше використання різноманітних технічних інновацій у практичній мистецько-освітній діяльності. Потреба здійснювати хорову практику в умовах карантину та дистанційного навчання змусила диригентів та керівників хорів шукати альтернативних способів реалізації хорового мистецтва, У результаті чого з'явився такий новий мистецький продукт, як віртуальний хор. Поглиблення інтеграції мистецтва й освіти засобами віртуальних комп'ютерних технологій можна вважати перспективним напрямом подальших досліджень.

\section{СПИСОК ВИКОРИСТАНИХ ДЖЕРЕЛ}

1. Бычков В. Виртуальная реальность как феномен современного искусства. Эстетика: Вчера. Сегодня. Всегда. Москва, 2006. № 2. С. 32-36. URL: http:// iph.ras.ru/page47631358.htm (дата звернення: 06.11.2020).

2. Віртуальне мистецтво. Вікіпедія. URL: https://uk.wikipedia.org/wiki/ Віртуальне_мистецтво\#сіte_note-2 (дата звернення: 06.11.2020).

3. Програми багатоканального зведення. Вiкinediя. URL: https:// uk.wikipedia.org/wiki/Програми_багатоканального_зведення\#: : text (дата звернення: 06.11.2020).

4. «Віртуальні хори» Еріка Вайтекера. Музика : украӥнський інтернет-журнал. URL: http://mus.art.co.ua/virtualnihory-erika-vajtekera (дата звернення: 05.11.2020).

5. Волинець В. Віртуальна реальність: поняття та сутність. Питання культурологї. 2014. № 30. С. 35-41. URL: http://nbuv.gov.ua/UJRN/Pkl_2014_30_6 (дата звернення: 06.11.2020).

6. Дубовий 3. Формування самостійності майбутніх вчителів музики у процесі дистанційного навчання : дис. ... канд. пед. наук: 13.00.02. Кривий Ріг, 2019. С. 200.

7. Заболоцький А. Сучасний стан дистанційного навчання у ВНЗ України. Вісник Дніпропетровського університету імені Альфреда Нобеля. Серія «Педагогіка і психологія». 2016. № 2. С. 19-23.

8. Іванов Ю. Особливості розвитку дистанційних технологій у ВНЗ Укоопспілки «Полтавський університет економіки і торгівлі». Вісник Національного університету «Львівська політехніка». Серія «Інформація вищого навчального закладу». 2017. № 879. С. 58-62.

9. Петелин Р., Петелин В. Steinberg Cubase 5: запись и редактирование музыки. Санкт-Петербург, 2010. С. 15.

10. Степаненко O. Adobe Audition 3.0. : создание фонограмм и обработка звука : научное пособие. Москва : Далектика, 2010. С. 97.

11. Чесноков П. Хор и управление им : пособие для хоровых дирижеров. Москва, 1961. С. 21.

12. Шадських Ю. Еволюція смислового значення поняття «віртуальна реальність». Вісник Національного університету «Львівська. політехніка». Серія «Філософські науки». 2012. № 723. С. 73-78.

13. Frank Popper. From Technological to Virtual Art. The MIT Press. URL: https:// www.researchgate.net/ publication/249562918_From_Technological_to_Virtual_Art_by_Frank_Popper (дата звернення: 06.11.2020).

14. Hegarty P. Rumour and Radiation: Sound in Video Art. New York : Bloomsbury Academic, an imprint of Bloomsbury Publishing Inc, 2015. P. 19.

15. Schroeder R. Possible Worlds. The Social Dynamic of Virtual Reality Technology. Popular Science \& Culture. Oxford: Westview Press, 1996. 203 p.

16. VivaCut - професійний редактор для відео. URL: https://www.naandroidi.top/programy-na-androyid/vivacutprofesijnyj-redaktor-dlya-video/ (дата звернення: 06.11.2020).

\section{REFERENCES}

1. Bychkov V. V. Vyrtualnaia realnost kak fenomen sovremennoho yskusstva. [Virtual reality as a phenomenon of contemporary art]. Aesthetics: Yesterday. Today. Always. Moskva, 2006. Nr 2. pp. 32-36. URL: http:// iph.ras.ru/page47631358. htm (data zvernennya: 06.11.2020). [in Russian].

2. Vikipediia: Virtualne mystetstvo. [Wikipedia: Virtual art]. URL: https://uk.wikipedia.org/wiki/Віртуальне мистецтво\#сіte_note-2 (data zvernennya: 06.11.2020). [in Ukrainian].

3. Vikipediaa: Prohramy bahatokanalnoho zvedennia. [Wikipedia: Multichannel compilation programs]. URL: https://uk.wikipedia.org/wiki/Програми_багатоканальногозведення\#: :text (data zvernennya: 06.11.2020). [in Ukrainian].

4. "Virtualni khory" Erika Vaitekera. [Eric Whitaker's "Virtual Choirs"]. Ukrainian online magazine "Music". URL: http://mus.art.co.ua/virtualni-hory-erika-vajtekera (data zvernennya: 05.11.2020). [in Ukrainian]. 
5. Volynets V. O. Virtualna realnist: poniattia ta sutnist. [Virtual reality: concept and essence]. Questions of culturology. 2014. № 30. pp. 35-41. URL: http://nbuv.gov.ua/UJRN/Pkl_2014_30_6 (data zvernennya: 06.11.2020). [in Ukrainian].

6. Dubovyi Z. S. Formuvannia samostiinosti maibutnikh vchyteliv muzyky u protsesi dystantsiinoho navchannia: dys. ... kand. ped. nauk : 13.00.02. [Formation of independence of future music teachers in the process of distance learning]. Kryvyi Rih, 2019. p. 200. [in Ukrainian].

7. Zabolotskyi A. Yu. Suchasnyi stan dystantsiinoho navchannia u VNZ Ukrainy. [The current state of distance learning in Ukrainian universities]. Visnyk Dnipropetrovskoho universytetu imeni Alfreda Nobelia. Seriia : Pedahohika i psykholohiia. 2016. № 2. pp. 19-23. [in Ukrainian].

8. Ivanov Yu. Osoblyvosti rozvytku dystantsiinykh tekhnolohii u VNZ Ukoopspilky "Poltavskyi universytet ekonomiky i torhivli". [Peculiarities of development of remote technologies in Ukoopspilka University "Poltava University of Economics and Trade"]. Visnyk Nats. un-tu “Lviv. Politekhnika”. Seriia: Informatsiia vyshch. navch. zakladu. 2017. № 879. pp. 58-62. [in Ukrainian].

9. Petelyn R. Yu., Petelyn V. Yu. Steinberg Cubase 5: zapys y redaktyrovanye muzyky. [Steinberg Cubase 5: record and edit music]. Sankt-Peterburh, 2010. p. 15. [in Russian].

10. Stepanenko O. S. Adobe Audition 3.0. : sozdanye fonohramm y obrabotka zvuka : nauch. posobye. [Adobe Audition 3.0. : creation of phonograms and sound processing: a scientific manual.]. Moskva : DYALEKTYKA, 2010. p. 97. [in Russian].

11. Chesnokov P. H. Khor y upravlenye ym: posobye dlia khorovykh dyryzherov. [Choir and its management: a manual for choral conductors.]. Moskva, 1961. p. 21. [in Russian].

12. Shadskykh Yu. Evoliutsiia smyslovoho znachennia poniattia "virtualna realnist". [Evolution of the semantic meaning of the concept of «virtual reality»]. Visnyk Nats. un-tu "Lviv. Politekhnika”. Seriia: Filosof. nauky. 2012. № 723. pp. 73-78. [in Ukrainian].

13. Frank Popper. From Technological to Virtual Art. The MIT Press. URL: https:// www.researchgate.net/publication/249562918_From_Technological_to_Virtual_Art_by_Frank_Popper (data zvernennya: 06.11.2020). [in English].

14. Hegarty P. Rumour and Radiation: Sound in Video Art. New York: Bloomsbury Academic, an imprint of Bloomsbury Publishing Inc, 2015. p. 19 [in English].

15. Schroeder R. Possible Worlds. The Social Dynamic of Virtual Reality Technology. Popular Science \& Culture. Oxford: Westview Press, 1996. 203 p. [in English].

16. VivaCut - profesiinyi redaktor dlia video. [VivaCut is a professional video editor]. URL: https://www.naandroidi.top/ programy-na-androyid/vivacut-profesijnyj-redaktor-dlya-video/ (data zvernennya: 06.11.2020). [in Ukrainian]. 